\title{
The Role of Social Media as a Measures of Information Delivery to Reduce the Risk of Flood Disasters in Kecamatan Pasar Kliwon, Surakarta City in 2020
}

\author{
Mikael Dafit Adi Prasetyo, Chatarina Muryani, Gentur Adi Tjahjono
}

Universitas Sebelas Maret

david.adiprasetyo97@gmail.com

Article History

accepted 31/08/2020

approved 22/09/2020

published 28/10/2020

\begin{abstract}
This study aims to perceptions and responses to flood disaster risk reduction social media in Pasar Kliwon District, Surakarta City, 2020. Utilization of whatsapp social media as a means of delivering information to the public in an effort to reduce disaster risk flooding in Pasar Kliwon Subdistrict, Surakarta City, 2020. the impact of the use of whatsapp social media as a means of delivering information on community efforts to reduce the risk of flood disasters in Pasar Kliwon District, Surakarta. The results of the study are as follows: Perception of flood disaster in Pasar Kliwon Subdistrict, if viewed from the potential of the disaster, it can be categorized as very large. For flood disaster vulnerability is also categorized as flood disaster prone. And disaster mitigation is carried out in the form of responsiveness and preparedness from stakeholders. Here the use of social media as a means of delivering flood disaster information.
\end{abstract}

Keywords: Social Media, Disaster Risk Reduction, Flooding

\section{Abstrak}

Penelitian ini bertujuan untuk mengetahui persepsi dan respon terhadap media sosial pengurangan risiko bencana banjir di Kecamatan Pasar Kliwon Kota Surakarta Tahun 2020. Pemanfaatan media sosial whatsapp sebagai sarana penyampaian informasi kepada masyarakat dalam upaya mengurangi risiko bencana banjir di Kecamatan Pasar Kliwon, Kota Surakarta, 2020. dampak penggunaan media sosial whatsapp sebagai sarana penyampaian informasi upaya masyarakat dalam mengurangi risiko bencana banjir di Kecamatan Pasar Kliwon Surakarta. Hasil penelitian sebagai berikut: Persepsi bencana banjir di Kecamatan Pasar Kliwon, jika dilihat dari potensi bencana dapat dikategorikan sangat besar. Untuk kerentanan bencana banjir juga dikategorikan sebagai rawan bencana banjir. Dan mitigasi bencana dilakukan dalam bentuk ketanggapan dan kesiapsiagaan dari para pemangku kepentingan. Disini pemanfaatan media sosial sebagai sarana penyampaian informasi bencana banjir.

Kata Kunci: Media Sosial, Pengurangan Risiko Bencana, Banjir

Social, Humanities, and Education Studies (SHEs): Conference Series https://jurnal.uns.ac.id/shes 


\section{PENDAHULUAN}

Indonesia merupakan negara beriklim tropis basah (humid tropic) dengan ciri khas memiliki curah hujan yang tinggi pada musim hujan. Akibatnya di beberapa tempat sering muncul genangan air atau bahkan menimbulkan bencana banjir. Setiap terjadi nya bencana banjir selalu menimbulkan kerugian bagi masyarakat baik harta benda bahkan nyawa manusia pun menjadi ancaman. Seiring datangnya musim hujan maka ancaman bencana banjir pun juga semakin tinggi, dengan lokasi dan tempat serta dengan tingkat kerusakan yang bermacam pula. Bencana banjir di Indonesia dari tahun ke tahun semakin meningkat jumlahnya. Luas lingkup wilayah banjir pun sekarang juga semakin bertambah luas. Jika dahulu banjir hanya melanda kota-kota besar di Indonesia seperti Jakarta, Bandung, Surabaya, Semarang, akan tetapi saat ini banjir sudah masuk ke wilayah dengan lingkup kecil, seperti di pedesaan. Banyak sekali faktor penyebab bencana banjir di antaranya: faktor musim penghujan, faktor retensi Daerah Aliran Sungai (DAS), faktor kesalahan perencanaan pembangunan alur sungai, faktor pendangkalan sungai dan faktor kesalahan tata wilayah dan pembangunan sarana dan prasarana (Hermon, 2012).

Di wilayah Surakarta pada bulan Maret 1966 terjadinya banjir besar yang merendam hampir 3/4 wilayah kota. Banjir yang terjadi di Surakarta pada tahun 1966 merupakan suatu pengulangan peristiwa dari banjir yang pernah terjadi di masa lampau. Perubahan pada bidang ekologi yang terjadi di Surakarta merupakan salah satu faktor penyebab adanya banjir. Presiden Soeharto mencetuskan pembangunan Waduk Serbaguna Wonogiri (Waduk Gajah Mungkur) guna menanggulangi bencana banjir agar tidak kembali terjadi di wilayah Sungai Bengawan Solo (Amelia, Kustyaswati. 2015). Memasuki musim penghujan, dua kecamatan di Kota Solo yakni Pasar Kliwon dan Jebres mendapat perhatian khusus Badan Penanggulangan Bencana Daerah (BPBD). Dua wilayah tersebut rawan banjir karena lokasinya berbatasan dengan Sungai Bengawan Solo. Selain kedua kecamatan itu, tiga kecamatan lainnya juga berpotensi banjir. Yakni di Kecamatan Laweyan, Serengan dan Banjarsari. (sumber: merdeka.com/7 Desember 2018).

Berbanding lurus dengan semakin meningkatnya bencana banjir yang terjadi. Meningkatnya penggunaan teknologi berupa telefon pintar di Indonesia dari tahun ke tahun semakin banyak. Data pengguna telepon pintar di Indonesia dari tahun 2016 sampai 2019 tercatat 65,2 juta pengguna telefon pintar di tahun 2016. Kemudian 74,9 juta pengguna di tahun 2017, 83,5 juta pengguna di tahun 2018, dan 92 juta pengguna di tahun 2018. Terjadi kenaikan $78 \%$ pengguna telepon pintar setiap tahunnya. (sumber: Emarketer 2015). Terlebih perkembangan jaman semakin membuat teknologi semakin berubah dan terus menerus berkembang. Salah satu platform media sosial bernama Hootsuite pada Juli 2017 sampai Januari 2018 merangkum sebuah data dari berbagai belahan dunia tentang media sosial paling banyak yang digunakan oleh warga masing-masing negara. Kebutuhan masyarakat terhadap konsumsi teknologi dan digitalisasi membuat perkembangan arus komunikasi dan informasi semakin cepat berkembang pesat.

Media sosial yang sering digunakan oleh masyarakat seperti Youtube, facebook, whatsapp, instagram, dan line. (sumber: nataconnexindo.com/2019). Perkembangan IImu Pengetahuan dan Teknologi atau IPTEK membuat masyarakat dengan mudah menerima dan membagikan informasi melalui media sosial.Tindakan mengurangi risiko bencana dapat dikatakan sebagai mitigasi bencana. Mengurangi risiko bencana tidak hanya dilakukan di satu tempat atau pun satu negara, melainkan negara-negara di dunia pun juga memiliki sistem mitigasi bencana terpadu. Hal ini sangat lah penting, mengingat bencana dapat terjadi kapan pun dan di mana pun. Mitigasi bencana juga saling berkaitan dengan kesiapsiagaan dari masyarakat. Mitigasi bencana juga merupakan bentuk tindakan preventif atau pencegahan supaya dampak yang di timbulkan dari bencana dapat di minimalisir dengan baik. Media sosial memiliki 
beberapa manfaat seperti penyebaran dan penyampaian informasi bencana banjir, mendorong masyarakat untuk terlibat sebagai sukarelawan bencana, dan memberikan bantuan kepada korban banjir (Velev Dimiter dan Zlateva Plamena, 2012). Seperti media sosial lainnya, pengguna twitter dapat menjalin komunikasi dengan pengguna lain, menyebar informasi, mempromosikan pendapat atau pandangan pengguna lain, sampai membahas isu terhangat (trending topic).

Badan Nasional Penanggulangan Bencana atau BNPB memiliki beberapa akun diberbagai platform media sosial, seperti YouTube, Instagram, Facebook, dan juga Twitter. Seperti di twitter BNPB memiliki akun resmi yang sudah terverifikasi dengan nama atau username @BNPB_Indonesia. Akun yang resmi bergabung pada bulan Agustus 2011 kini sudah memiliki 180 ribu pengikut. Di sini peran stake holder atau pemangku kepentingan juga sangat berpengaruh, misalnya dari Badan Penanggulangan Bencana Daerah (BPBD), Palang Merah Indonesia (PMI), Search and Rescue atau (SAR), Kepala Kecamatan (Camat) dan Kepala Kelurahan (Lurah) hingga ketua Rukun Warga dan Rukun Tetangga (RW dan RT).

Arus penyampaian informasi mengenai bencana hendaknya disampaikan dengan menggunakan bahasa yang baik, dan mudah dimengerti oleh masyarakat. Berbeda dengan jaman dahulu di mana sistem peringatan dini bencana/Early Warning System masih menggunakan peralatan tradisional dan sederhana. Namun saat ini di jaman yang sudah memasuki era digitalisasi dan industri 4.0 membuat upaya mengurangi risiko bencana pun dapat dibagikan melalui media apa saja, termasuk melalui media sosial. Perkembangan Early System di Indonesia saat ini bisa dikatakan lebih maju. Hal ini terbukti dengan adanya tiga produk inovasi tersebut yakni Tsunami Early Warning System (INATEWS) 4.0

\section{METODE}

Penelitian ini dilakukan Kecamatan Pasar Kliwon, Kota Surakarta. Jenis penelitian ini adalah penelitian deskriptif penelitian yang lebih mengarah pada pengungkapan suatu masalah atau keadaan sebagaimana adanya dan mengungkapkan fakta-fakta yang ada, walaupun kadang diberikan interpretasi atau analisis. Populasi yang digunakan adalah masyarakat yang terdampak bencana banjir khususnya di Kecamatan Pasar Kliwon, Kota Surakarta. Dengan unit analisis yaitu Kelurahan/Desa. Selain masyarakat juga terdapat pemangku kepentingan (stakeholder) diantara nya BPBD Kota Surakarta, Kecamatan Pasar Kliwon, Kelurahan Semanggi, Sangkrah, Pasar Kliwon, Kedung Lumbu, dan Joyosuran beserta dengan tokoh masyarakat seperti ketua RT dan RW. Sample penelitian ini diambil dari masyarakat yang pernah terdampak bencana banjir di Kecamatan Pasar Kliwon, Kota Surakarta yakni warga Kelurahan Joyosuran (RT 03 RW 03, RT 02 RW 03, dan RT 01 RW 03). Warga Kelurahan Sangkrah (RT 02 RW 03, RT 04 RW 11). Warga Kelurahan Kedung Lumbu (RT 01 RW 01, dan RT 04 RW 07). Warga Kelurahan Semanggi (RT 02 RW 03, dan RT 05 RW 13). Warga Kelurahan Pasar Kliwon (RT 02 RW 03, dan RW 12). Teknik pengumpulan data berupa observasi, wawancara, dan dokumentasi. Sedangkan untuk teknik analisis data yaitu pengumpulan data, reduksi data, penyajian data, dan penarikan kesimpulan atau verifikasi.

\section{Deskripsi Wilayah Penelitian}

\section{HASIL DAN PEMBAHASAN}

Daerah penelitian meliputi Kecamatan Pasar Kliwon, Kota Surakarta secara astronomis terletak antara $110^{\circ}$ dan $111^{\circ}$ Bujur Timur dan antara 7,6 으 dan 8. Lintang Selatan. Secara administrasi Pasar Kliwon dibagi menjadi 10 Kelurahan/desa, Luas Kecamatan Pasar Kliwon, Kota Surakarta yaitu 4,82 km². Kecamatan Pasar Kliwon, Kota Surakarta memiliki iklim tropis dengan suhu rata-rata $24,2^{\circ} \mathrm{C}$ sampai $32,2^{\circ} \mathrm{C}$. Rata-rata tekanan udara adalah 1010,9 MBS dengan kelembaban udara $75 \%$. 
Kecepatan angin 4 Knot dengan arah angin 240 derajat. Sedangkan Menurut klasifikasi iklim Koppen, Surakarta memiliki iklim muson tropis. Sama seperti kota-kota lain di Indonesia, musim hujan di Solo dimulai bulan Oktober hingga Maret, dan musim kemarau bulan April hingga September. Rata-rata curah hujan di Solo adalah 2.200 $\mathrm{mm}$, dan bulan paling tinggi curah hujannya adalah Desember, Januari, dan Februari.

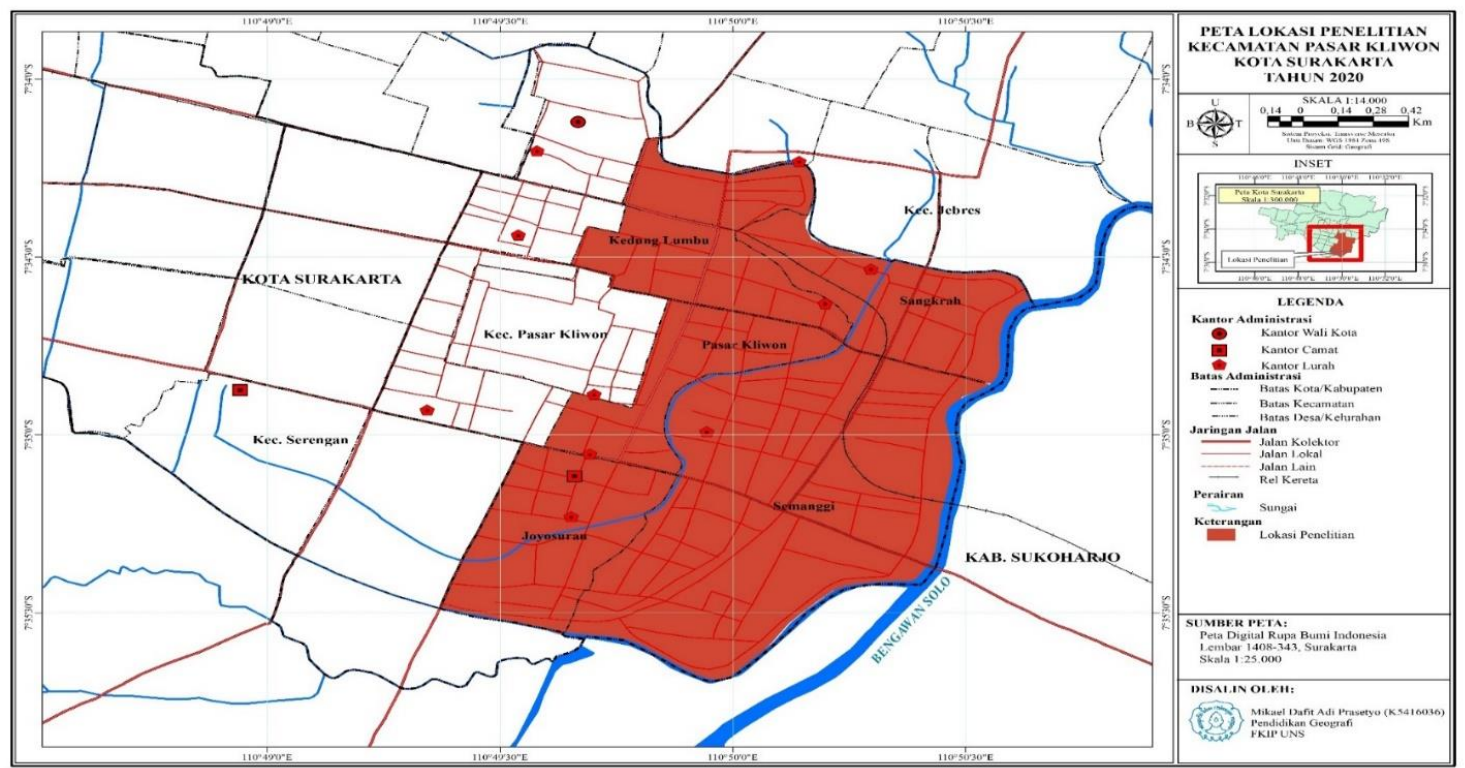

Gambar 1. Peta Lokasi Penelitian di Kecamatan Pasar Kliwon Kota Surakarta Tahun 2020

\section{Persepsi Masyarakat Terhadap Bencana Banjir}

Persepsi masyarakat terhadap upaya pengurangan risiko bencana banjir di Kecamatan Pasar Kliwon adalah suatu bentuk tanggapan berdasarkan informasi yang diterima oleh masyarakat. Antara masyarakat satu dengan yang lain, memiliki persepsi yang berbeda-beda. Indikator persepsi masyarakat dalam hal pengurangan risiko bencana banjir terdiri atas potensi bencana banjir, kerawanan bencana banjir, dan mitigasi bencana banjir. Potensi bencana banjir di Kecamatan Pasar Kliwon yang meliputi daerah penelitian di Kelurahan Pasar Kliwon, Joyosuran, Semanggi, Sangkrah, dan Kedung Lumbu memiliki potensi dan kerawanan bencana banjir yang sangat besar berdasarkan pada $48 \%$ responden menjawab sangat besar. Hal ini karena adanya beberapa faktor seperti, Kecamatan Pasar Kliwon berdekatan langsung dengan Sungai Bengawan Solo, sedangkan yang berbatasan langsung yaitu Kelurahan Semanggi, Sangkrah, Kedung Lumbu, Pasar Kliwon, dan Joyosuran. Indikator lainnya yaitu tingkat kerawanan bencana banjir di Kecamatan Pasar Kliwon Kota Surakarta masuk ke dalam kategori rawan banjir dengan 39\% responden menjawab rawan. Tidak semua wilayah penelitian menjadi daerah yang rawan bencana banjir. Ada beberapa wilayah tertentu yang sangat rawan hingga tidak rawan sama sekali. Wilayah yang rawan banjir di antara nya, RW 1, 2, 3, 4, 5, 6, 10, 11, 12,13 (Kelurahan Sangkrah), RW 2,3,4 dan 5.serta RW 13 dan 14 (Kelurahan Semanggi), RW 12 dan RT 1,2,3 (Kelurahan Pasar Kliwon), RW 1, 3, dan 7 (Kelurahan Kedung Lumbu), RW 03 (RT 01,02,03) dan RW 12 (RT 02,03,dan 04) (Kelurahan Joyosuran). Hal ini diperkuat dengan penyataan dari Kasi Pencegahan dan Kesiapsiagaan Bencana BPBD yaitu Bapak Sumarno, Untuk Kecamatan Pasar Kliwon, Kelurahan yang rawan banjir adalah Semanggi, Sangkrah, Kedung Lumbu, Joyosuran, dan Pasar Kliwon. Hal ini karena letak kelurahan tersebut berbatasan dengan Sungai Jenes, Sungai Pepe dan Sungai Bengawan Solo.

Langkah mitigasi bencana yang dilakukan oleh pihak stakeholder di Kecamatan Pasar Kliwon yang mencakup wilayah penelitian menegaskan bahwa, peran 
stakeholder selalu tanggap dan siap siaga jika sewaktu-waktu terjadi bencana banjir dan mempersiapkan segala hal jika bencana banjir sudah terjadi. Hal ini ditunjukkan dari 30 Kepala Keluarga atau sekitar 33\% Kepala Keluarga sudah merasakan bantuan dari stakeholder yang selalu tanggap dan siap siaga bencana. Selain itu ada beberapa langkah mitigasi yang dilakukan yaitu melaksanakan keduk walet, di jalan serayu, cempaka, dan sampangan (kegiatan besar) selain itu terdapat pula kerja bakti. Sehingga persepsi bencana banjir di Kecamatan Pasar Kliwon, jika dilihat dari potensi bencana nya dapat dikategorkan sangat besar, untuk kerawanan bencana banjir dikategorikan rawan bencana banjir dan mitigasi bencana yang dilakukan berupa tanggap dan kesiap siagaan dari stakeholder.

\section{Pemanfaatan media sosial whatsapp terhadap upaya Pengurangan Risiko Bencana banjir di Kecamatan Pasar Kliwon, Kota Surakarta}

Pemanfaatan media sosial merupakan suatu bentuk menggunakan media sosial sebagai sarana penyampaian informasi untuk Pengurangan Risiko Bencana banjir dengan mengacu pada beberapa indikator seperti, mekanisme penyampaian infromasi, jenis media sosial, dan aksesibilitas atau cara mengakses media sosial.

Dari hasil pengambilan sampel penelitian diketahui bahwa responden menggunakan media sosial sebagai sarana penyampaian informasi Pengurangan Risiko Bencana banjir di Kecamatan Pasar Kliwon 56\% responden memilih media sosial. Selain itu penggunaan media sosial sebagai sarana penyampaian informasi mengenai bencana banjir juga diperkuat dengan pernyataan dari kepala kelurahan, dengan keunggulan media sosial yang dianggap cepat, efektif dan lebih dekat dengan masyarakat. Selain itu media sosial yang digunakan oleh stakeholder dan masyarakat dalam penyampaian informasi mengenai mitigasi bencana banjir lebih banyak menggunakan media sosial whatsapp (76\% masyarakat memilih whatsapp). Media sosial whatsapp adalah media sosial yang digunakan sebagai sarana berbagi pesan dengan aneka fitur menarik. Tidak hanya bisa berbagi pesan teks saja, melainkan ada video, gambar, maupun lokasi. Sehingga menjadikan whatsapp mudah untuk menemukan lokasi genangan air jika sewaktu-waktu masyarakat ingin menyampaikan nya kepada stakeholder. Dari hasil pengambilan sampel penelitian di atas dapat diketahui bahwa, Masyarakat di Kecamatan Pasar Kliwon yang menjadi responden penelitian sangat mudah menggunakan atau mengakses media sosial (71\% responden memilih sangat mudah). Karena kemudahan inilah yang membuat proses kolaborasi antara stakeholder terkait dengan warga masyarakat dalam hal pengurangan risiko bencana banjir begitu solid dan cepat tanggap. Akses internet di lokasi penelitian pun juga tergolong bagus untuk semua provider layanan internet sehingga tidak ada hambatan dalam hal penyebaran informasi dan komunikasi baik dari stakeholder maupun warga masyarakat. Sehingga dapat disimpulkan bahwa pemanfaatan merupakan suatu cara yang digunakan untuk menghasilkan sesuatu. Disini pemanfaatan media sosial sebagai sarana penyampaian informasi bencana banjir. Media sosial yang dimanfaatkan adalah whatsapp. Pemangku kepentingan (stakeholder) dan masyarakat lebih memilih menggunakan whatsapp karena mudah mengakses informasi.

3. Dampak penggunaan media sosial whatsapp sebagai sarana penyampaian informasi pengurangan risiko bencana banjir.

Dari hasil pengambilan sampel penelitian di atas dapat diketahui bahwa, dampak penggunaan media sosial khususnya whatsapp di lokasi penelitian menujukkan bahwa mitigasi bencana banjir melalui peran media sosial whatsapp sangat besar dimasyarakat (44\% responden memilih sangat besar). Dengan menggunakan media sosial whatsapp masyarakat akan lebih mudah untuk saling berkomunikasi dan berbagi informasi apabila terjadi tanda-tanda akan datang bencana banjir. Masyarakat pun dengan mudah akan saling berkoordinasi dengan stakeholder terkait dalam hal mitigasi bencana banjir. 
Hubungan masyarakat merupakan suatu bentuk pengelolaan untuk penyebaran informasi mengenai mitigasi bencana banjir antara stakeholder dan warga masyarakat.

Dari hasil pengambilan sampel penelitian di atas dapat diketahui bahwa, pengaruh media sosial whatsapp terhadap hubungan antara stakeholder dengan warga masyarakat yaitu mudah untuk saling berkomunikasi (48\% responden memilih mudah berkomunikasi). Dengan kemudahan berkomunikasi pula membuat warga masyarakat juga memiliki rasa solidaritas tinggi apabila terjadi bencana banjir membuat warga masyarakat saling gotong royong memberikan bantuan kepada masyarakat yang terdampak bencana banjir. Sehingga dapat disimpulkan bahwa dampak merupakan pengaruh yang ditimbulkan akibat sesuatu hal yang dilakukan. Dampak yang ditimbulkan dari penggunaan media sosial sebagai sarana penyampaian informasi pengurangan risiko bencana banjir sangat besar dalam hal penggunaan media sosial whatsapp dalam penyampaian informasi dari stakeholder kepada masyarakat. Sedangkan pengaruh hubungan stakeholder dengan masyarakat dengan adanya media sosial whatsapp adalah kemudahan dalam berkomunikasi.

\section{SIMPULAN}

Berdasarkan hasil analisis penelitian maka diperoleh kesimpulan sebagai berikut:

1. Persepsi bencana banjir menurut hasil wawancara dengan masyarakat di Kecamatan Pasar Kliwon, dapat dikategorkan sangat besar. Untuk kerawanan bencana banjir pun menurut hasil wawancara dengan masyarakat dikategorikan rawan bencana banjir. Dan mitigasi bencana yang dilakukan berupa tanggap dan siap siaga

Pemanfaatan media sosial sebagai sarana penyampaian informasi bencana banjir. Media sosial yang dimanfaatkan adalah whatsapp. Pemangku kepentingan (stake holder) dan masyarakat lebih memilih menggunakan whatsapp karena mudah

2. Dampak yang ditimbulkan dari penggunaan media sosial sebagai sarana penyampaian informasi Pengurangan Risiko Bencana banjir yakni sangat besar yakni dalam hal penggunaan media sosial whatsapp untuk sarana penyampaian informasi bencana banjir dari stakeholder kepada masyarakat. Dampak yang sangat besar ini dapat digambarkan dengan cepat nya arus penyampaian informasi mengenai bencana banjir dan pengurangan risiko bencana banjir kepada masyarakat, sehingga jika banjir terjadi masyarakat bisa langsung mengungsi.

\section{DAFTAR PUSTAKA}

Computers in Hu A.A.K. (2011). Jaringan Sosial Tanpa Web. India

American Red Cross. (2011). Ulasan Program Layanan Bencana. AS

Arikunto. (2004). Prosedur Penelitian Suatu Pendekatan Praktek,

Edisi Kelima, Rineka Cipta, Jakarta.

Budiarti, Wiwin. (2017) Upaya Mitigasi Banjir di Sub DAS Samin Melalui Pengembangan Masyarakat Tangguh Bencana

Bird, Deanne and friends. (2012). Flooding Facebook - The Use of Social Media during the Queensland and Victorian Floods. RiskFrontiers,Macqua rie University, North Ryde, Australia 2109.

BNPB. (2005). Bencana Banjir dan faktor penyebabnya

Durkheim dalam Fuchs . (2014). Perilaku Penggunaan Media Sosial beserta Implikasinya

Fahriyani, Silvi. dkk. (2019). Penggunaan Media Sosial Twitter untuk Mitigasi Bencana di Indonesia. Fikom

UPI YAI

Hermon, Dedi. (2012), Mitigasi Bencana Hidrometeorologi. Padang: UNP press. 
Kustyaswati, Amelia. (2015) . Banjir Solo 1966: Sebuah Sejarah Sosial. Universitas Gadjah Mada. Yogyakarta

Lestari, Puji. dkk. (2018). Pemberitaan di Media Online untuk Pengurangan Risiko Bencana Gunung Sinabung. Universitas Pembangunan Nasional Veteran Yogyakarta dan Universitas Al Azhar Indonesia.

Sandhyavitri, Ari dkk. (2015). Mitigasi Bencana Banjir dan Kebakaran. Universitas Riau Press. Pekanbaru 